\title{
IMPLEMENTASI PENELITIAN TINDAKAN KELAS
}

\author{
Slameto \\ slameto_usw@yahoo.com \\ Pendidikan Guru Sekolah Dasar \& PPS-MP - FKIP - UKSW Salatiga
}

\begin{abstract}
ABSTRAK
Dalam tahap Penelitian Tindakan Kelas (PTK), langkah merencanakan merupakan langkah pertama. Tanpa rencana, kegiatan yang kita lakukan tidak akan terarah. Rencana akan menjadi acuan dalam melaksanakan tindakan. Melakukan tindakan sebagai langkah yang kedua. Tanpa tindakan, rencana hanya merupakan angan-angan yang tidak pernah menjadi kenyataan. Dalam implementasi PTK tahap merencanakan dan melakukan tindakan terdiri dari langkah utama yaitu: mengidentifikasi masalah, menganalisis dan merumuskan masalah, merencanakan tindakan kelas, melaksanakan tindakan kelas (membuat perencanaan, melaksanakan, observasi, analisis dan refleksi), mengumpulkan data dan menganalisis data tentang proses dan hasil beserta tindak-lanjutnya; terakhir adalah menulis laporan. Langkahlangkah ini merupakan langkah yang berurutan; artinya langkah pertama harus dikerjakan lebih dahulu sebelum langkah kedua dilaksanakan, demikian seterusnya.
\end{abstract}

Kata kunci: PTK: Perencanaan, Pelaksanaan, Observasi, Analisis dan Refleksi, Pengumpulan dan Analisis Data, Tindak-Lanjut, Penulisan Laporan

\section{PENDAHULUAN}

Rencana penelitain dan pelaksanaa penelitian tindakan kelas (ptk) Dalam tahap PTK, langkah merencanakan merupakan langkah pertama. Tanpa rencana, kegiatan yang kita lakukan tidak akan terarah atau sering disebut dengan "ngawur". Rencana akan menjadi acuan dalam melaksanakan tindakan. Melakukan tindakan sebagai langkah yang kedua merupakan dari rencana yang kita buat. Tanpa tindakan, rencana hanya merupakan angan-angan yang tidak pernah terjadi kenyataan. Dalam bab ini, kita akan mengkaji dua tahap, yaitu tahap merencanakan dan melakukan tindakan dengan 4 langkah utama yaitu: Mengidentifikasi masalah Menganalisis dan merumuskan masalah Merencanakan PTK Melaksanakan PTK Keempat langkah ini merupakan langkah yang berurutan; artinya langkah pertama harus dikerjakan lebih dahulu sebelum langkah kedua dilaksanakan, demikian seterusnya. Langkah pertama dan kedua merupakan bagian awal dari merencanakan perbaikan, sedangkan langkah yang ketiga merupakan prasyarat untuk langkah yang keempat. 


\section{TAHAP PERENCANAAN}

\section{Merasakan Adanya Masalah}

Hal yang sangat diperlukan agar guru dapat menerapkan PTK sebagai upaya memperbaiki dan/atau meningkatkan layanan pembelajaran secara lebih profesional, guru dituntut untuk berani mengatakan secara jujur mengenai beberapa sisi lemah yang masih terdapat dalam implementasi program pembelajaran yang dikelola. Dengan kata lain, guru harus mampu merefleksi, merenung, berpikir balik, mengenai apa saja yang telah dilakukan dalam proses pembelajaran dalam rangka mengidentifikasikan sisi-sisi lemah yang mungkin ada. Dalam proses perenungan itu, terbuka peluang untuk menemukan kelemahan-kelemahan praktik pembelajaran yang selama ini mungkin dilakukan secara tanpa disadari.

Permasalahan yang diangkat dalam PTK harus benar-benar merupakan masalah-masalah yang dihayati guru dalam praktik pembelajaran, bukan praktik yang disarankan, apalagi ditentukan oleh pihak luar termasuk oleh kepala sekolah yang menjadi mitra. Permasalahan tersebut dapat berangkat (bersumber) dari siswa, guru, bahan ajar, kurikulum, interaksi pembelajaran, dan hasil belajar siswa.

\section{Mengidentifikasi dan Menganalisisi Masalah}

Suatu rencana PTK diawali dengan adanya masalah yang dirasakan atau disadari oleh guru. Hal ini sesuai dengan salah satu karateristik PTK, yaitu masalah berasal dari orang yang terlibat dalam praktik, dalam hal ini guru sebagai pengelola pembelajaran. Guru merasa bahwa sudah mengajar dengan baik, sesuai standar proses, tetapi ada sesuatu yang tidak beres di kelasnya, yang jika dibiarkan akan berdampak buruk bagi proses dan hasil belajar siswa kelak kemudian hari. Misalnya ada sekelompok siswa yang secara terus menerus membuat kesalahan yang sama, ada siswa yang suka membolos, atau hasil belajar siswa menurun secara drastis. Setelah guru menyadari masalah yang dirasakan, guru dapat mengajukan pertanyaan kepada diri sendiri. Untuk menjawab pertanyaan itu, guru perlu merenung atau melakukan refleksi tentang apa yang terjadi di dalam kelas. Refleksi akan efektif jika guru mempunyai pemahaman atau kesadaran yang tinggi akan fungsi pembelajaran dan jujur terhadap diri sendiri. Jika setelah menjawab pertanyaan tersebut guru sampai pada kesimpulan bahwa ia memang menghadapi masalah dalam bidang tertentu, berarti ia sudah berhasil mengidentifikasi masalah. Jika masalah sudah teridentifikasi, mungkin muncul pertanyaan, masalah mana yang mungkin dipecahkan melalui PTK? Apakah semua masalah layak dipecahkan melalui PTK? Untuk menjawab pertanyaan ini, rambu-rambu dapat dijadikan pegangan.

Bidang yang layak dijadikan fokus PTK adalah yang:

1. melibatkan kegiatan belajar mengajar 
2. mungkin ditangani guru

3. sangat menarik minat guru

4. ingin diubah/diperbaiki oleh guru.

Permasalahan yang diangkat dalam PTK harus benar-benar merupakan masalahmasalah yang dihayati guru dalam praktik pembelajaran, bukan praktik yang disarankan, apalagi ditentukan oleh pihak luar termasuk oleh kepala sekolah yang menjadi mitra. Permasalahan tersebut dapat berangkat (bersumber) dari siswa, guru, bahan ajar, kurikulum, interaksi pembelajaran, dan hasil belajar siswa

Setelah masalah teridentifikasi, kita perlu melakukan analisis sehingga dapat merumuskan masalah dengan jelas. Tanpa melakukan analisis, mungkin masalah yang kita identifikasi masih kabur. Analisis dapat dilakukan dengan mengajukan pertanyaan kepada diri sendiri atau yang disebut refleksi, dan dapat pula dengan mengkaji ulang berbagai dokumen seperti pekerjaan siswa, daftar hadir, atau daftar nilai, atau bahkan mungkin bahan pelajaran yang kita siapkan. Semua ini tergantung dari jenis masalah yang kita identifikasi. Masalah yang dirasakan atau pernah dialami dapat dicatat.

Kita bisa bertanya kepada diri sendiri, misalnya:

(1) Apa yang sedang terjadi sekarang?

(2) Apakah yang sedang terjadi itu mengandung permasalahan?

(3) Apa yang bisa saya lakukan untuk mengatasinya?

Pada tahap ini yang paling penting adalah menghasilkan gagasan-gagasan awal mengenai permasalahan aktual yang dialami guru di kelas. Dengan berangkat dari gagasan-gagasan awal tersebut, guru dapat berbuat sesuatu untuk memperbaiki keadaan dengan menggunakan PTK.

Setelah identifikasi masalah dapat dilakukan, peneliti -secara individu atau bermitra dengan guru lain- melakukan analisis terhadap masalah-masalah tersebut untuk menentukan urgensi pengatasan. Dengan kegiatan tersebut akan dapat ditemukan permasalahan yang sangat mendesak untuk diatasi. Tidak perlu ditekankan lebih kuat lagi bahwa analisis masalah perlu dilakukan secara cermat sebab keberhasilan pada tahap analisis masalah akan menentukan keberhasilan keseluruhan pelaksanaan PTK. Jika PTK berhasil dilaksanakan dengan membawa kemanfaatan yang dapat dirasakan dan dapat dirasakan pula oleh sekolah, keberhasilan ini akan menjadi motivasi bagi guru untuk meneruskan usaha di masamasa yang akan datang. Di samping itu, temuan-temuan yang dihasilkan melalui PTK itu akan menarik bagi guru lain yang belum mengikuti program PTK untuk juga mencoba melaksanakannya.

\section{Perumusan Masalah}

Setelah menetapkan fokus permasalahan serta menganalisisnya menjadi bagian-bagian yang lebih kecil, selanjutnya perlu merumuskan permasalahan secara 
lebih jelas, spesifik, dan operasional. Perumusan masalah yang jelas akan membuka peluang untuk menetapkan tindakan perbaikan (alternatif solusi) yang perlu dilakukannya, jenis data yang perlu dikumpulkan termasuk prosedur perekamannya serta cara menginterpretasikannya, khususnya yang perlu dilakukan sementara tindakan perbaikan dilaksanakan dan data mengenai proses dan/atau hasilnya itu direkam. Di samping itu, penetapan tindakan perbaikan yang akan dilakukan itu juga memberikan arahan kepada peneliti untuk melakukan berbagai persiapan termasuk yang berbentuk pelatihan guna meningkatkan keterampilan untuk melakukan tindakan perbaikan yang dimaksud.

\section{Merencanakan Perbaikan}

Langkah-langkah dalam menyusun rencana adalah sebagai berikut: 1) rumuskan cara perbaikan yang akan ditempuh dalam bentuk hipotesis tindakan dan 2) analisis kelayakan hipotesis tindakan.

\section{Formulasi solusi dalam bentuk hipotesis tindakan}

Alternatif tindakan perbaikan juga dapat dilihat sebagai hipotesis yang mengindikasikan dugaan mengenai perubahan atau perbaikan yang akan terjadi jika suatu tindakan dilakukan. Hipotesis tindakan merupakan tindakan yang diduga akan dapat memecahkan masalah yang ingin diatasi dengan penyelenggaraan PTK. Hipotesis tindakan adalah dugaan guru tentang cara yang terbaik untuk mengatasi masalah. Dugaan atau hipotesis ini dibuat berdasarkan kajian berbagai teori, kajian hasil penelitian yang pernah dilakukan dalam masalah yang serupa, diskusi dengan teman seprofesi atau dengan pakar, serta refleksi pengalaman sendiri sebagai guru. Berdasarkan hasil kajian tersebut, guru menyusun berbagai alternative tindkaan. Selanjutnya guru perlu mengkaji setiap alternative, terutama keterkaitannya dengan tujuan tindakan (perbaikan) serta kelayakan pelaksanaannya. Akhirnya dengan mempertimbangakan hasil kajian, guru memilih alternative yang dianggap paling layak. berikut ini.

Agar dapat menyusun hipotesis tindakan dengan tepat, lakukan kegiatan

(1) Pengkajian teoretik di bidang pembelajaran/pendidikan.

(2) Pengkajian hasil-hasil penelitian yang relevan dengan permasalahan.

(3) Diskusi dengan rekan sejawat, pakar pendidikan, peneliti lain, dan sebagainya.

(4) Pengkajian pendapat dan saran pakar pendidikan khususnya yang dituangkan dalam bentuk program.

(5) Perefleksian pengalaman saudara sebagai guru. 


\section{Analisis kelaikan hipotesis tindakan}

Setelah menetapkan alternative hipotesis yang terbaik, hipotessis ini masih perlu dikaji kembali kelayakannya dikaitkan dengan kemungkinan pelaksanaannya yaitu:

a. Kemampuan dan komitmen guru sebagai actor pelaksana karena pelaksanaan PTK memang harus tumbuh dari keinginan guru sendiri.

b. Kemampuan dan kondisi fisik siswa dalam mengikuti tindakan tersebut.

c. Ketersediaan sarana atau fasilitas yang diperlukan.

d. Iklim belajar dan iklim kerja di sekolah. Iklim belajar berkaitan dengan berbagai kebiasaan guru, siswa dan personil lain dalam menyikapi kegiatan belajar atau kegiatan akademik, sedangkan iklim kerja berkaitan dengan kebiasaan personil sekolah dalam menyikapi tugas-tugasnya.

\section{MELAKUKAN TINDAKAN}

\section{Persiapan Tindakan}

Sebelum PTK dilaksanakan, tim perlu melakukan berbagai persiapan sehingga semua komponen yang direncanakan dapat dikelola dengan baik. Langkah-langkah persiapan yang perlu ditempuh itu adalah sebagai berikut:

(1) Membuat rencana pembelajaran beserta skenario pembelajaran yang berisikan langkah-langkah yang dilakukan guru di samping bentuk-bentuk kegiatan yang dilakukan siswa dalam rangka implementasi tindakan perbaikan yang telah direncanakan;

(2) mempersiapkan fasilitas dan sarana pendukung yang diperlukan di kelas, seperti lembar kerja siswa, gambar-gambar dan alat-alat peraga;

(3) mempersiapkan cara merekam dan menganalisis data mengenai proses dan hasil tindakan perbaikan, kalau perlu juga dalam bentuk pelatihan-pelatihan;

(4)melakukan simulasi pelaksanaan tindakan perbaikan untuk menguji keterlaksanaan rancangan sehingga dapat menumbuhkan serta mempertebal kepercayaan diri dalam pelaksanaan yang sebenarnya. Sebagai aktor PTK, guru harus terbebas dari rasa takut gagal dan takut berbuat kesalahan.

\section{Melaksanakan tindakan}

Jika semua tindakan persiapan telah selesai, skenario tindakan perbaikan yang telah direncanakan itu dapat dilaksanakan dalam situasi yang aktual. Kegiatan pelaksanaan tindakan perbaikan ini merupakan tindakan pokok dalam siklus PTK, dan pada saat yang bersamaan kegiatan pelaksanaan ini juga disertai dengan kegiatan observasi dan interpretasi serta diikuti dengan kegiatan refleksi. 
Agar pelaksanaan dapat berlangsung dengan baik dan terarah, guru perlu memperhatikan beberapa prinsip yang oleh Hopkins (1993) disebut dengan kriteria PTK yang dilakukan oleh guru sebagai berikut:

a. Pekerjaan utama guru adalah mengajar. Oleh karena itu metode penelitian yang sedang dilakukan tidak boleh mengganggu komitmen guru dalam mengajar. Guru tidak boleh mengorbankan siswa demi penelitian yang sedang dilaksanakannya.

b. Cara pengumpulan atau perekaman data jangan sampai terlalu menyita waktu guru,sehingga guru sampai kehabisan waktu. Esensi pelaksanaan PTK memang harus disertai dengan observasi dan interpretasi dan pengumpul data yang paling baik adalah guru. Guru dapat memanfaatkan alat perekam seperti tape recorder atau meminta bantuan teman sejawat.

c. Metode yang diterapkan haruslah reliable atau handal, sehingga memungkinkan guru mengembangkan strategi pembelajaran yang sesuai dengan situasi kelasnya.

d. Masalah yang ditangani guru haruslah sesuai dengan kemampuan dan komitmen guru.

e. Sebagai peneliti, guru harus memperhatikan berbagai aturan atau etika yang terkait dengan tugas-tugasnya.

f. PTK harus mendapat dukungan dari seluruh personil sekolah. Artinya semua personil sekolah harus punya persepsi yang benar tentang PTK dan apa yang ingin dicapai melalui PTK.

Dalam pelaksanaan PTK observasi dan interpretasi terhadap proses dan hasilbelajar harus dilaksanakan secara bersamaan.

\section{Observasi dan Interpretasi}

Observasi adalah segala upaya merekam segala peristiwa dan kegiatan yang terjadi selama tindakan perbaikan itu berlangsung dengan atau tanpa alat bantu. Dalam PTK, yang diobservasi adalah tindakan guru menerapkan pembelajaran yang baru beserta respon siswa dalam mengikuti pembelajaran itu. Observasi dilakukan pada semua kegiatan yang ditunjukkan untuk mengenali, merekam, dan mendokumentasikan setiap indikator dari proses dan hasil yang dicapai baik yang ditimbulkan oleh tindakan terencana maupun akibat sampingan. Kegiatan observasi atau monitoring dapat dilakukan sendiri oleh peneliti dan/atau kolaborator, yang memang diberi tugas untuk hal itu. Pada saat monitoring pengamat haruslah mencatat semua peristiwa atau hal yang terjadi di kelas yang dilakukan PTK. Misalnya masalah kompetensi guru, situasi kelas, sikap dan perilaku siswa, penyajian atau pembahasan materi, daya serap siswa terhadap materi yang diajarkan dan sebagainya. 
Fungsi diadakannya observasi pada penelitian tindakan dapat dibedakan menjadi dua, yaitu: 1) untuk mengetahui kesesuaian pelaksanaan tindakan dengan rencana tindakan yang telah disusun dapat diharapkan akan menghasilkan perubahan kearah yang diinginkan. Yang terpenting dari kegiatan pengamatan adalah dapat mengenali sejak dini apakah tindakan yang dilakukan mengarah kepada terjadinya perubahan proses pembelajaran sesuai yang diharapkan. Dapat terjadi pelaksanaan tindakan tidak menghasilkan perubahan apapun atau kearah yang tidak diinginkan, misalkan penyebabnya, dan menentukan langkah perbaikan berikutnya. Pelaksanaan pengamatan yang terpenting adalah mencari data tentang pelaksanaan dari rancangan tindakan, karena itu peneliti harus cermat menentukan metode, teknik dan mempersiapkan alat yang tepat agar data yang diperoleh benarbenar sahih (valid) dan dapat diandalkan (reliabel). Hal ini berarti perlu diusahakan agar kegiatan observasi tidak terlalu mengganggu malahan membebani guru dalam melaksanakan tugas pokoknya sebagai pengelola proses pembelajaran di kelasnya. 2) Data yang terkumpul saat observasi secepatnya dianalisis dan diinterpretasi, sehingga akan segera diketahui apakah tindakan yang dilakukan telah mencapai tujuan. Interpretasi atau pemaknaan hasil observasi ini menjadi dasar untuk melakukan evaluasi sehingga dapat disusun langkah berikutnya dalam pelaksanaan tindakan.Yang penting dicatat pada kesempatan ini adalah kadar interpretasi yang terlibat dalam rekaman hasil observasi. Sesuai dengan hakikat data yang dikehendaki observasi harus dilakukan secara bersamaan dengan interpretasi.

\section{Pengumpulan dan Analisis Data}

Seperti telah diuraikan di atas, pelaksanaan tindakan disertai dengan observasi atau pengamatan dan sekaligus interpretasi terhadap data tentang proses yaitu tindakan guru dan respon siswa serta hasil tindakan, yang tentu saja terfokus pada perilaku mengajar guru, perilaku belajar siswa, dan interaksi antara guru dan siswa, sehingga dapat dikatakan pelaksanaan tindakan dan obserevasi/ interpretasi berlangsung simultan. Artinya data yang diperoleh dengan pengamatan tersebut langsung diinterpretasikan, tidak sekedar direkam. Namun, perlu dicatat, tidak semua data memerlukan interpretasi. Ada hasil pengamatan yang hanya merupakan rekaman faktual tanpa memerlukan interpretasi, sehingga pengamat cukup hanya merekam apa yang dilihat tanpa perlu memberi makna kepada hasil rekamannya.

Pengumpulan data dilakukan oleh guru sebagai peneliti selama proses pelaksanaan tindakan. Pengumpulan data dapat dilakukan selain dengan teknik observasi, perlu juga dengan teknik wawancara, catatan harian, angket dan sebagainya.

Wawancara dapat dilakukan misalnya untuk mengungkap pendapat siswa tentang pemebelajaran. Dalam hal ini, wawancara dapat terjadi anatara guru dan 
siswa, pengamat dan siswa, serta siswa dan siswa, sedangkan wawancara antara pengamat dan guru terjadi pada tahap pertemuan pendahuluan dan diskusi balikan/refleksi. Agar wawancara dapat berlangsung efektif, suasana yang kondusif harus diciptakan terlebih dahulu. Terakhir, bukti-bukti berupa dokumen, seperti hasil belajar siswa, yang dapat berupa tugas, hasil latihan, atau ulangan dapat dimanfaatkan sebadai data yang dapat memberi informasi tentang kualitas perbaikan.

Catatan harian/jurnal kegiatan guru yang sering disebut field note, dibuat oleh guru segera setelah pembelajaran selesai. Guru dapat mencatat peristiwaperistiwa penting dalam pembelajaran, seperti partisipasi siswa yang dianggap istimewa, reaksi guru yang menimbulkan berbagai resppons dari siswa yang dianggap istimewa, atau kesalahan yang dibuat oleh siswa karena guru membuat kekeliruan. Catatan ini akan sangat berharga bagi guru karena merupakan hasil observasi, reaksi, dan refleksi guru terhadap pembelajaran yang dikelolanya. Disamping itu, catatan harian guru dapat merupakan rekaman perkembangan guru dalam melaksanakan tugas sebagai guru.

Agar data yang diperoleh dari berbagai alat/teknik tersebut bermakna sebagai dasar untuk mengambil keutusan, data tersebut harus dianalisis atau diberi makna. Analisis data pada tahap ini agak berbeda dengan interpretasi yang dilakukan pada tahap observasi. Jika interpretasi dilakukan pada setiap saatobservasi dan pada pertemuan atau diskusi balikan/refleksi, maka analisis data dilakukan setelah satu paket perbaikan (siklus) telah diimplementasikan secara keseluruhan. Misalnya, jika perbaikan ini direncanakan untuk empat kali pemberlajaran, maka analisis data dilakukan setelah keempat pembelajaran tuntas dilaksanakan. Dengan demikian, pada setiap pembelajaran akan terjadi interpretasi yang dimanfaatkan untuk melakukan penyesuaian, dan pada akhir paket perbaikan (siklus) diadakan analisis data secara keseluruhan untuk menghasilkan informasi yang dapat menjawab hipotesis perbaikan yang dirancang guru. Analisis data dapat dilakukan secara bertahap, pertama dengan menyeleksi dan mengelompokkan, kedua dengan memaparkan atau mendeskripsikan data, dan terakhir menyimpulkan atau memberi makna.

\section{Refleksi}

Pada prinsipnya yang dimaksud dengan istilah refleksi adalah upaya evaluasi yang dilakukan oleh para kolaborator atau partisipan yang terkait dengan suatu PTK yang dilakukan. Karena itu refleksi dalam PTK dilakukan: 1) pada saat memikirkan tindakan apa yang akan dilakukan, 2) ketika tindakan sedang dilakukan, dan 3) setelah tindakan itu dilakukan. Kegiatan refleksi tidak hanya 
terfokus pada diri guru sendiri, akan tetapi mencakup seluruh konteks pembelajaran yang dilakukannya bahkan termasuk siswa dan lingkungannya.

Kegiatan refleksi mencakup kegiatan analisis, interpretasi dan evaluasi yang diperoleh saat melakukan kegiatan observasi. Guru merenungkan secara intens apa yang telah terjadi dan tidak terjadi, mengapa segala sesuatu terjadi dan/atau tidak terjadi, serta menjajaki alternatif-alternatif solusi yang perlu dikaji, dipilih, dan dilaksanakan untuk dapat mewujudkan apa yang dikehendaki. Secara teknis, refleksi dilakukan dengan melakukan analisis dan sintesis, di samping induksi dan deduksi. Suatu proses analitik terjadi jika objek kajian diuraikan menjadi bagianbagian, serta dicermati unsur-unsurnya. Sementara itu, suatu proses sintetik terjadi apabila berbagai unsur objek kajian yang telah diuraikan tersebut dapat ditemukan kesamaan esensinya secara konseptual sehingga dapat ditampilkan sebagai suatu kesatuan.

Salah satu aspek penting dari kegiatan refleksi adalah melakukan evaluasi terhadap keberhasilan dan pencapaian tujuan tindakan. Aspek penting lainnya dari kegiatan refleksi adalah terjadinya peningkatan dalam profesionalisasi jabatan guru. Karena salah satu indikasi guru yang professional adalah adanya keinginan untuk perubahan demi perbaikan proses pembelajaran yang dilakukan dan pelayanan yang diberikan pun secara berkelanjutan. Untuk keperluan ini guru dituntut untuk berani melakukan evaluasi diri secara terus menerus dan terancana, sehingga upaya perbaikan pembelajaran dapat terus berlanjut.

Berdasarkan hasil observasi dan evaluasi tersebut, guru melakukan refleksi terhadap proses dan hasil tersebut yang akan menjadi dasar bagi perencanaan berikutnya, tindakan tambahan yang perlu dilakukan, dan sebagainya melalui siklus kegiatan pengajaran berikutnya. Dalam kegiatan refleksi ini biasanya guru melibatkan peserta didik dalam bentuk diskusi. Berdasarkan berbagai balikan tersebut yang diperoleh saat diskusi, maka guru menimbang-nimbang pengalaman yang diperoleh, mana yang termasuk dipakai dan mana yang masih perlu ditambahkan pada pengajaran berikutnya. Apabila dicermati, dalam proses refleksi tersebut dapat ditemukan komponen-komponen sebagai berikut.

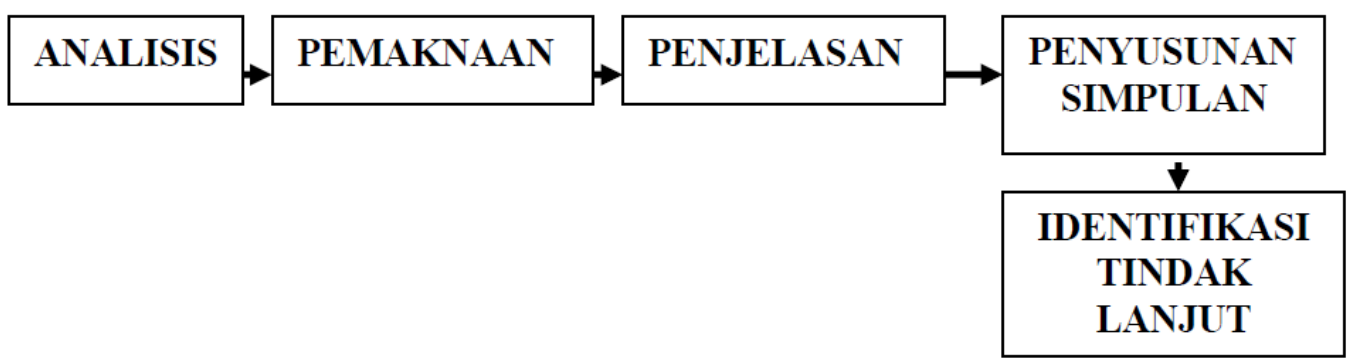

Gambar Proses Refleksi dalam Penelitian 
Jika hasilnya belum memuaskan atau masalahnya belum terselesaikan sampai dengan akhir siklus, maka dilakukan tindakan perbaikan lanjutan dengan memperbaiki tindakan perbaikan dengan metode tetap sama dengan sebelumnya, atau, dengan menyusun tindakan perbaikan yang betul-betul baru untuk mengatasi masalah yang ada.

\section{Perencanaan Tindak Lanjut}

Pada tahap refleksi dananalisis data, hasil atau kesimpulan yang didapat pada analisis data setelah melakukan refleksi digunakan untuk membuat rencana tidak lanjut. Jika ternyata tindakan perbaikan belum berhasil menjawab masalah yang menjadi kerisauan guru, maka hasil analisis data dan refleksi digunakan untuk merencanakan kembali tindakan perbaikan, bahkan bila perlu dibuat rencana baru. Jika ini terjadi maka akan terdapat siklus 2 PTK yang langkah-langkahnya tetap sama, yaitu perumusan masalah, perencanaan tindakan, pelaksanaan tindakan, observasi dan interpretasi, serta analisa data dan refleksi. Siklus ini akan berulang kembali jika pada siklus 2, tindakan perbaikan masih belum berhasil menjawab masalah, dengan perkataan lain perbaikan belum terjadi sesuai dengan yang ditargetkan. Siklus PTK akan berakhir, jika perbaikan sudah berhasil dilakukan. Perlu dicatat bahwa satu siklus PTK dapat terjadi pada minimal 3 pertemuan. Lebihlebih untuk tujuan perbaikan yang membutuhkan waktu cukup lama, seperti meningkatkan kemampuan menulis, maka satu siklus PTK dapat terdiri dari beberapa pertemuan.

\section{PENYUSUNAN LAPORAN PENELITIAN}

Laporan PTK pada umumnya terdiri dari 5 bab, bab 1, bab 2 dan bab 3 dikembangkan dari proposal yang telah disahkan Kepala Sekolah. Dalam penulisan bab 4 Hasil Penelitian dan Pembahasan, peneliti terlebih dulu menyajikan paparan data yang mendeskripsikan secara ringkas apa saja yang dilakukan peneliti sejak pengamatan awal (sebelum penelitian) yaitu kondisi awal guru dan siswa diikuti refleksi awal yang merupakan dasar perencanaan tindakan siklus I, dilanjutkan dengan paparan mengenai pelaksanaan tindakan, hasil observasi kegiatan guru, observasi situasi dan kondisi kelas dan hasil observasi kegiatan siswa. Paparan data itu kemudian diringkas dalam bentuk temuan penelitian yang berisi pokok-pokok hasil observasi dan evaluasi yang disarikan dari paparan data.

Berikutnya berdasarkan temuan data dilakukan refleksi hasil tindakan siklus 1 yang dijadikan dasar untuk merencanakan tindakan untuk siklus ke 2. Di sini dapat dibandingkan hasil siklus 1 dengan indikator keberhasilan tindakan siklus 1 yang telah ditetapkan berdasarkan refleksi awal.Paparan data siklus dua juga 
lengkap mulai perencanaan, pelaksanaan, observasi dan evaluasi. Ringkasan paparan data dicantumkan dalam bentuk temuan penelitian. Temuan ini menjadi dasar refleksi tindakan siklus ke 2, termasuk apakah perlu dilanjutkan dengan pelaksanaan tindakan untuk siklus ke 3 (jika ada). Peneliti dapat membandingkan hasil siklus 2 ini dengan indikator keberhasilan tindakan siklus 2 yang telah ditetapkan berdasarkan hasil refleksi tindakan siklus ke 1. Jadi prosedur analisis dan interpretasi data penelitian dilaksanakan secara deskriptif kualitatif dengan meringkas data (reduksi data), saturasi dan triangulasi. Penulisan dilanjutkan dengan melakukan pembahasan hasil yang dicapai dengan PTK. Bab 5 Penutup, memaparkan kesimpulan dan saran.

\section{PENUTUP}

PTK merupakan salah satu sarana belajar sepanjang hayat yang penting yang perlu dikuasai oleh setiap guru dalam mengembangkan keprofesionalannya.Dalam implementasi PTK terdapat beberapa langkah penelitian yang harus dilalui oleh peneliti; langkah merencanakan merupakan langkah pertama. Tanpa rencana, kegiatan penelitian yang akan kita lakukan tidak akan terarah. Rencana akan menjadi acuan dalam melaksanakan tindakan. Melakukan tindakan sebagai langkah yang kedua. Tanpa tindakan, rencana hanya merupakan angan-angan yang tidak pernah menjadi kenyataan.

Dalam implementasi PTK tahap merencanakan dan melakukan tindakan terdiri dari langkah utama yaitu: mengidentifikasi masalah, menganalisis dan merumuskan masalah, merencanakan tindakan kelas, melaksanakan tindakan kelas (membuat perencanaan, melaksanakan, observasi, analisis dan refleksi), mengumpulkan data dan menganalisis data dan hasil beserta tindak-lanjutnya. Pada akhirnya adalah menulis laporan.

Langkah-langkah implementasi ini merupakan langkah yang berurutan; artinya langkah pertama harus dikerjakan lebih dahulu sebelum langkah kedua dilaksanakan, demikian seterusnya.

\section{DAFTAR RUJUKAN}

Depdikbud. 1999. Bahan Pelatihan Penelitian Tindakan. Jakarta: Depdikbud, Dirjen Dikdasmen, Dikmenum.

Erni Panca. 2014. Penelitian Tindakan Kelas. http://ernipanca.blogspot.co.id/ 2014/10/penelitian-tindakan-kelas.html.

Herawati Susilo \& Kisyani Laksono. 2008. Penelitian Tindakan Kelas - Prosedur Analisis dan Interpretasi Data Penelitian. https://ptkguru.wordpress.com/ 2008/05/11/penelitian-tindakan-kelas\%E2\%80\%94prosedur-analisis-daninterpretasi-data-penelitian/ 
Intan Khoirun Nisa. 2014. Prosedur dan Pelaksanaan Penelitian Tindakan Kelas. http://sedikitbicarabanyakilmu.blogspot.co.id/2014/01/prosedur-danpelaksanaan-penelitian.html

Navel Oktaviandy. 2012. Penelitian Tindakan Kelas (Suatu Reflektif dalam Perbaikan Kualitas Pembelajaran). https://navelmangelep.wordpress.com/ 2012/03/19/penelitian-tindakan-kelas-suatu-reflektif-dalam-perbaikankualitas-pembelajaran/

Nurhadi. 2013. Implementasi Model Penelitian Tindakan Kelas. https://sd2 bulungkulon.wordpress.com/2013/05/13/implementasi-model-penelitiantindakan-kelas/

Sarwiji Suwandi, 2013. Modul Pendidikan dan Latihan Profesi Guru (PLPG): Penelitian Tindakan Kelas, Surakarta: Panitia Sertifikasi Guru Rayon 113 Universitas Sebelas Maret

Slameto, 2015. Penelitian dan Inovasi Pendidikan. Salatiga: Satya Wacana University Press

Tim PGSM. 1999. Penelitian Tindakan Kelas (Classroom Action Research). Bahan Pelatihan Dosen LPTK dan Guru Sekolah Menengah. Jakarta: Proyek PGSM, Dikti. 